KALAM, P-ISSN: 0853-9510 E-ISSN: 2540-7759

http://ejournal.radenintan.ac.id/index.php/KALAM

Volume 10, No. 2, Desember 2016, halaman 537 - 554

\title{
Revitalisasi Desa Adat \\ Berbasis Pendidikan dan Kearifan Lokal
}

\author{
Erlina Rufaidah \\ Universitas Lampung \\ deris.aa99@gmail.com
}

\begin{abstract}
Abstrak
Kehadiran desa adat dinilai mampu menjadi wadah yang dapat mengakomodasi berbagai kepentingan budaya sebagai bentuk pelestariannya. Sebuah desa adat berjalan dengan baik apabila berjalannya berbagai aspek pendukung lainnya di antaranya aspek pendidikan dan kearifan lokal. Peran pendidikan dasar dan kesadaran kearifan lokal dalam hal ini menjadi sangat penting, sebagai upaya untuk mencegah munculnya sikap-sikap tersebut sejak dini. Kajian ini bertujuan untuk menjawab persoalan bagaimana wujud revitalisasi desa adat berbasis pendidikan dan kearifan lokal pada masyarakat Kabupaten Lampung Barat. Sebagai bentuk revitalisasi pada aspek pendidikan peningkatkan kesiapan guru dalam menghadapi berbagai tantangan dan tuntutan zaman kedepan dan pengembangan kompetensi budaya sebagai salab satu aspek kompetensi guru diperlukan untuk meningkatkan efektivitas dan kebermaknaan program pendidikan pada berbagai jenis dan jenjang. Selain itu, termuatnya pandangan bidup yang bersumber dari kearifan lokal sangatlah penting mengingat nilai-nilai dasar kultural yang ada di dalam kearifan lokal melekat pada diri masyarakat. Memegang teguh nilai-nilai kearifan lokal dan mengimplementasikannya pada kehidupan bermasyarakat akan
\end{abstract}


mampu menjadi solusi atas timbulnya permasalahan sosio-kultural di dalam masyarakat.

\begin{abstract}
The presence of indigenous villages judged capable of becoming a container that can accommodate a variety of cultural interests as a form of preservation. A traditional village work properly if the operation of several other ancillary aspects of which aspects of education and local wisdom. The role of basic education and awareness of local wisdom in this case is very important, in an effort to prevent these attitudes from an early age. This study aims to answer the question of how a form of revitalization of traditional village-based education and indigenous community of $W$ est Lampung regency. As part of the revitalization of the educational aspect of enhancing the readiness of teachers in meeting the challenges and demands of the times in the future and the development of cultural competence as one of the aspects of teacher competence is needed to improve the effectiveness and meaningfulness of education programs at the various types and levels. Additionally, termuatnya view of life that comes from local knowledge is important to remember the basic cultural values that exist in the local wisdom inherent in society. Uphold the values of local wisdom and implements it in social life will be able to be a solution for the generation of sociocultural issues in masyarakat.
\end{abstract}

Key Words: Desa Adat, Pendidikan, Kearifan Lokal

\title{
A. Pendahuluan
}

Indonesia adalah sebuah Negara kepulauan dengan jumlah pulau terbanyak di dunia. Hal ini yang kemudian menjadikan Indonesia memiliki kekayaan budaya dan adat istiadat yang sangat beragam. Bahkan tercatat terdapat sekitar 1331 suku budaya yang ada di Indonesia. Sebagai konsekuensi dari banyaknya pulau di Indonesia serta budaya dan adat istiadat yang ada maka kehidupan masyarakatnya pun menjadi sangat multikultur. Kehidupan multikultur tersebut terbingkai dengan harmonis atas dasar "bhineka tunggal ika" dan slogan ini seolah telah menjadi ruh tersendiri dalam kehidupan berbangsa dan bernegara ditengahtengah kemajemukan ras, agama, suku, budaya, dan karakter 
masyarakat yang beragam. Suku dan budaya terdapat hampir merata di setiap Provinsi di Indonesia dan seolah menjadi sebuah entitas kebanggaan daerah, suku dan budaya lahir dan terus terjaga oleh masyarakat ditengah-tengah arus globalisasi dan modernisasi yang terus menggerus.

Dinamika ketatanegaraan di Indonesia sekarang ini semakin memberikan akses yang signifikan dengan memberikan kejelasan status desa dalam sistem pemerintahan Republik Indonesia. Kejelasan status sesuai dengan yang termaktum dalam UndangUndang No 6 Tahun 2014 tentang Desa memiliki arti penting mengingat ini akan memberikan kemandirian lebih bagi desa untuk mengembangkan potensi lokal, memberikan akses pelayanan publilk kepada masyarakat, yang pada akhirnya akan memberikan kesejahteraan yang merata bagi masyarakatnya. ${ }^{1}$

Desa adat sebagai lembaga tradisional otonom, komunitas budaya tradisional, kesatuan masyarakat hukum adat, dan identitas kolektif masyarakat memiliki perbedaan dengan desa non"adat", dimana desa adat adalah kesatuan masyarakat hukum adat yang masih ada, dan tidak bertentangan dengan kepentingan dan prinsip NKRI. Dari sekian banyak desa adat yang ada dan masih terjaga hingga sekarang salah satunya adalah desa adat di Kabupaten Lampung Barat.

Kata desa adat digunakan untuk penyesuaian regulasi pemerintahan, kemudian searah dengan berkembangnya wacana pemurnian tradisi dan nilai budaya dalam desa adat, identitas desa adat pun dikembalikan ke nama desa adat. Setelah lahirnya perda desa adat, sebagai aktualisasi identitas budaya, nilai lokal dan budaya, desa adat ditetapkan kembali sebagai nama, penanda dan tatanan budaya, nilai dan adat-istiadat di Kabupaten Lampung Barat.

${ }^{1}$ Undang-Undang Republik Indonesia Nomor 6 Tahun 2014 Tentang Desa. Dalam ketentuan umum Pasal 1 disebutkan bahwa Desa adalah desa dan desa adat atau yang disebut dengan nama lain, selanjutnya disebut Desa, adalah kesatuan masyarakat hukum yang memiliki batas wilayah yang berwenang untuk mengatur dan mengurus urusan pemerintahan, kepentingan masyarakat setempat berdasarkan prakarsa masyarakat, hak asal usul, dan/atau hak tradisional yang diakui dan dihormati dalam sistem pemerintahan Negara Kesatuan Republik Indonesia. 
Kesadaran budaya multikultur yang pluralis, tentunya harus sudah tertanam pada diri individu sejak dini agar terhindar dari sikap egosektoral. Tujuannya adalah agar konflik sosial yang sering terjadi di tengah-tengah masyarakat dapat diminimalisir dan bahkan teratasi. Peran pendidikan dasar dan kesadaran kearifan lokal dalam hal ini menjadi sangat penting, sebagai upaya untuk mencegah munculnya sikap-sikap tersebut sejak dini.

Tolok ukur yang sekaligus menjadi indikator desa adat berjalan dengan baik ialah berjalannya berbagai aspek pendukung lainnya diantaranya aspek pendidikan dan kearifan lokal. Aspek pendidikan menjadi salah satu pondasi penting dalam keberlangsungan desa adat. Seiring dengan perkembangan kebudayaan manusia, timbulah tuntutan akan adanya pendidikan yang terselenggara dengan baik, lebih teratur dan didasarkan atas pemikiran yang matang.

Dalam tataran desa adat pada masyarakat Kabupaten Lampung Barat pendidikan telah menjadi salah satu unsur adat yang harus terpenuhi. Mulai dari sistem pendidikan yang ada sampai dengan ujung tombak terdepan pendidikan yaitu guru atau tenaga pendidik. Sebagaimana kita ketahui kualitas masa depan bangsa ditentukan dari kualitas tenaga pendidik hari ini.

Seiring dengan perkembangan zaman yang terus maju dan berkembang maka tenaga pendidik pun dituntut untuk dapat terus mengeksplore kualitas diri dan pengajarannya. Institusi pendidikan guru berada pada poisi yang menentukan dalam reformulasi pendidikan karena lembaga ini bertanggungjawab dalam mempersiapkan guru pada berbagai jenis dan jenjang pendidikan. ${ }^{2}$ Perubahan kebijakan dibidang pendidikan yang terus bergerak dinamis memaksa para tenaga pendidik harus siap dengan semua tantangan kedepan. Perubahan kurikulum yang seolah terlalu cepat dan terus berubah disertai tanpa adanya sosialisasi yang merata membuat para tenaga pendidik seolah kehilangan arah tak terkecuali tenaga pendidik yang ada di desa adat Kabupaten Lampung Barat. Kebijakan yang di buat dan cenderung berubah berefek langsung kepada tenaga pendidik yang ada karena kesiapan

2 Al-Musanna, Artikulasi Pendidikan Guru Berbasis Kearifan Lokal Untuk Mempersiapkan Guru yang Memilki Kompetensi Budaya (Aceh Tengah: STAIN Gajah Putih Takengon, 2012) dalam Jurnal Pendidikan dan Kebudayaan, Vol. 18, Nomor 3. 
mereka yang masih rendah sehingga mereka masih belum memahami apa dan bagaimana mengimplementasikan kurikulum tersebut.

Apabila guru tidak paham maka akan terjadi ketidakjelasan dalam proses pembelajaran sehingga standar kompetensi lulusan pun tidak tercapai. Bahkan apabila problematika itu terus dibiarkan dampak lebih lanjut yang akan terjadi adalah kualitas mutu pendidikan di desa adat Kabupaten Lampung Barat akan menurun sehingga berdampak langsung pada penurunan kualitas sumber daya manusia di desa adat tersebut.

Selain dikarenakan faktor kurikulum yang berubah secara cepat dan tanpa adanya sosialisasi yang merata. Masalah tersebut seolah diperparah dengan kompetensi guru berbasis budaya dan kearifan lokal di desa adat Kabupaten Lampung Barat yang masih dibawah standar yang diharapkan. Hal itu terjadi karena perilaku malas yang sudah menjadi kebiasaan bagi sebagian tenaga pendidik ditambah lagi dengan rasa keinginan untuk berbuat lebih.yang masih sangat minim. Disamping itu juga kreatifitas serta inovasi yang dilakukan masih sangat kurang sehingga hal tersebut cenderung membuat perilaku konsumtif di kalangan tenaga pendidik.

Lembaga pendidikan guru dituntut memberi perhatian untuk mempersiapkan guru yang mempunyai kompetensi budaya sebagai prasyarat yang memungkinkan guru untuk beradaptasi dengan peserta didik yang mempunyai latar belakang ras, etnis, kelas sosial, dan bahasa yang beragam. ${ }^{3}$

Keragaman konteks dan latar belakang budaya peserta didik menuntut kualifikasi guru yang tidak hanya menguasai disiplin ilmu dan kecakapan pedagogis, tetapi juga mempersyaratkan guru yang mampu beradaptasi dan mengintegrasikan pemahamannya terhadap keragaman budaya peserta didik dalam praktik pembelajaran baik itu berbasis pada budaya lokal maupun kearifan lokal yang ada.

Pendidikan guru tanggap budaya mempersyaratkan adanya pengakuan bahwa budaya merupakan sistem nilai yang dinamis yang di dalamnya mencakup kode pengetahuan (cognitive codes),

3 Villegas, A.M. Lucas, T. 2002 Preparing Culturally Responsive Teachers: Rethinking Curriculum. Journal of Teacher Education, 53 (1), 20-32. 
standar prilaku (behavioral standars), pandangan hidup (world views), dan keyakinan (beliefs) yang berfungsi sebagai piñata keseimbangan dan pemberi makna kehidupan. ${ }^{4}$

Kearifan lokal merupakan salah satu produk kebudayaan. Sebagai produk kebudayaan kearifan lokal lahir karena kebutuhan akan nolai, norma, dan aturan yang menjadii model untuk (model for) melakukan sesuatu. ${ }^{5}$ Kearifan lokal merupakan salah satu sumber pengetauan (kebudayaan) masyarakat, ada dalam tradisi dan sejarah, dalam pendidikan formal dan informal, seni, agama, dan interpretasi keratif lainnya.

Perhatian terhadap keragaman kearifan lokal semakin menemukan rasionalitasnya. Penelitian ini memandang bahwa kearifan lokal secara substansial mengandung nilai hidup yang termanifestasikan dalam aturan- aturan sosial atau pun aturan adatistiadat. Bagi Tilaar kearifan lokal mempunyai nilai pedagogis karena bertujuan untuk mengatur tingkah laku yang bermanfaat bagi kepentingan bersama masyarakat. ${ }^{6}$

Secara lebih spesifik, kearifan lokal dapat dikelompokkan menjadi lima: kearifan yang berupa pandangan hidup, kepercayaan atau ideology yang diungkapkan dalam kata-kata bijak (filosofi); kearifan yang berupa sikap hidup sosial, nasihat atau iktibar yang diungkap dalam bentuk pepatah, perumpamaan, pantun syair atau cerita rakyat (folklor); kearifan berupa ritus atau seremoni dalam bentuk upacara; kearifan yang berupa prinsip, norma, dan tata aturan bermasyarakat yang berwujud menjadi sistem sosial; dan kearifan yang berupa kebiasaan, prilaku sehari-hari dalam pergaulan sosial. $^{7}$

Pada tataran implementasi, manifestasi atas kearifan lokal belum terealisasikan secara nyata, sehingga institusi pendidikan perlu mewadahi potensi kelokalan tersebut menjadi satu materi yang

${ }^{4}$ Gay, G, Culturally Responsive Teaching: Theory, Research and Practice (New York: Teacher College, 2000).

A. Syafi'I Mufid, Revitaliasi Kebudayaan Lokal dalam Pemberdayaan Masyarakat (Peneliti Utama Puslitbang Kehidupan Keagamaan) dalam Jurnal Multikultural dan Multireligius, Vol. IX, Nomor 34.

${ }^{6}$ Tilaar, H.A.R, Pedagogik Teoritis untuk Indonesia. (Jakarta: Buku Kompas, 2015).

7 Rasyidin, Siregar, P. Batubara, K, Penyerapan Nilai-Nilai Budaya Lokal dalam Kehidupan Beragama: Studi Tentang Budaya Lokal di Medan dalam Afif dan Bahri, S.Ed, Harmonisasi Agama dan Budaya di Indonesia. (Jakarta: Balitbang Kemenag, 2009), h. 236. 
cukup implementatif dan dapat dikontektualisasikan dengan seluruh mata pelajaran yang relevan. Perlunya dilakukan secara implementatif dan konkrit, karena saat ini proses internalisasi atas nilai-nilai kearifan lokal kepada peserta didik masih berhenti ditataran konseptual dan belum mewujud pada implementasi kehidupan.

Nilai-nilai yang terkandung dalam kearifan lokal diharapkan dapat tetap hidup dan menghidupi masyarakatnya. Bahkan melalui kearifan lokal dapat menguatkan aspek etika atau moral individu masyarakatnya. Hal ini cukup relevan mengingat masyarakat dalam menyelenggarakan kehidupan tidak dapat terlepas dari pengaruh lingkungan tempat mereka hidup, hubungan timbal balik dan kait mengkait antara nilai filosofis dan cita-cita kolektif.

Menurut Harsya unsur-unsur budaya selalu hadir dalam setiap interaksi sosial dan bahwa unsur-unsur budaya itu tidak mengambang bebas di udara, melainkan merupakan bagian dari sistem-sistem yang mengakar pada pribadi-pribadi. ${ }^{8}$ Kontekstualisasi pengetahuan atas kearifan lokal sebagai penguatan karakter peserta didik menjadi satu hal yang urgen untuk dilakukan. Hal ini disebabkan arus globalisasi dan modernisasi yang terus menggerus jati diri bangsa. Terlebih di tahuntahun mendatang Indonesia akan dihadapkan dengan berbagai kerjasama luar negeri dan kegiatan berskala Internasional yang cukup kompetitif dan terbuka dan tidak menutup kemungkinan ini akan menjadi peluang sekaligus tantangan untuk terus menjaga dan menjunjung tinggi keragaman kearifan lokal sebagai identitas dan corak khusus bangsa Indonesia. Realitas tersebut apabila tidak disikapi secara serius dengan memikirkan langkah konkrit dan rencana strategis yang matang, sangat mungkin keberagaman kearifan lokal menjadi terabaikan bahkan dimungkinkan lenyap tergerus arus zaman.

Bukti kearifan lokal yang terabaikan ini terlihat ketika nilainilai lokal tidak terserap dan mewujud dalam perilaku kehidupan sehari-hari. Padahal jika kearifan lokal termanifestasikan dalam perilaku atau sikap hidup, identitas masyarakat pemiliknya turut

${ }^{8}$ Bachtiar, Harsya, W, Konsesnsus dan Konflik dalam Sistem Budaya di Indonesia, dalam Harsya. W. Bachtiar, Mattulada, Haryati Soebadio. Budaya dan Manusia Indonesia (Yogyakarta: Hanindita, 1985). 
terbentuk. Apalagi karakteristik Indonesia yang multikultur kearifan lokal cukup beragam dan masing-masing memiliki kekhasan dengan kandungan nilai-nilai luhur jati diri bangsa Indonesia.

Namun pada kenyataan yang ada, kearifan lokal justru tergerus oleh tatanan gaya hidup yang di dalamnya mengandung nilai pragmatis, hedonis, dan kapitalistik. Beriringan dengan itu maka munculah berbagai permasalahan di masyarakat seperti bentrok antar warga, pergaulan bebas, penyalahgunaan narkoba, persaingan yang berujung pertikaian, korupsi, sikap individualistik, dan lain sebagainya. Padahal pendidikan dan gaya hidup adalah dua hal yang secara ontologis berlainan. Pada kasus tersebut, proses pendidikan dengan menjadikan kearifan lokal penting untuk direalisasikan.

Menyadari luasnya cakupan pembahasan maka fokus permasalahan yang akan dikaji yaitu (1) Bagaimana wujud revitalisasi desa adat berbasis pendidikan pada masyarakat Kabupaten Lampung Barat? (2) Bagaimana wujud revitalisasi desa adat berbasis kearifan lokal pada masyarakat Kabupaten Lampung Barat? Kedua pertanyaan tersebut menjadi pijakan atas dilakukannya kajian ini, dan diharapkan melalui penelitian ini dapat memberikan simpulan yang bermanfaat serta mampu menjadikan pendidikan dan kearifan lokal sebagai basis kemajuan desa adat.

Secara metodologis, penelitian ini menggunakan metode penelitian kualitatif. Data yang digunakan adalah data kualitatif. Data diperoleh dari kajian pustaka dan observasi. Data dikategorikan menjadi tiga, yakni data mengenai desa adat, pendidikan, dan kearifan lokal. Pengkategorian data membantu peneliti untuk memahami konsep-konsep dasar. Menurut Anselm Strauss dan Juliet Corbin pemberian kategori data bertujuan agar peneliti dapat mengingatnya, membahasnya, dan mengembangkannya secara analitik. ${ }^{9}$

\section{B. Pembahasan}

Dalam konteks budaya dan masyarakat hadirnya desa adat

9 Strauss, Anselm dan Corbin, Juliet, Dasar-dasar Penelitian Kualitatif, Tatalangkah dan Teknik-teknik Teoritisasi Data (Yogyakarta: Pustaka Pelajar, 2009). 
sebagai wadah pemersatu antara keragaman budaya dan kehidupan bermasyarakat akan sangat relevan dijalankan sebagai satu kesatuan utuh yang terintegrasi dengan adat istiadat yang ada. Desa adat mampu dijadikan solusi sebagai media penghubung antara kehidupan sosial budaya yang majemuk dengan dibatasi aturan-aturan adat istiadat yang berlaku dan menjadi pedoman dalam bermasyarakat.

Desa adat sebagai ranah manifestasi antara masyarakat majemuk dengan adat istiadat sebagai identitas budaya akan mampu mengakomodir kesadaran budaya multikultur yang pluralis. Kemajuan desa adat akan sangat berpengaruh langsung kepada kemajuan suatu daerah karena desa adat merupakan sarana yang paling dekat dan bersentuhan langsung dengan masyarakat sehingga apabila sebuah desa adat mampu berkembang, mandiri, dan maju maka desa adat sebagai basis suatu daerah akan memberikan efek positif yang sama terhadap kemajuan daerah tersebut.

Kemajuan desa adat sangat bergantung dari berbagai komponen pendukung yang cukup penting salah satunya yaitu aspek pendidikan dan aspek kearifan lokal. Revitalisasi desa adat dapat dilakukan dengan dengan berbagai cara salah satu diantaranya yaitu dengan merevitalisasi komponen pendukung kemajuan desa adat tersebut. Apabila pendidikan dan kearifan lokal sebagai aspek pendukung kemajuan sebuah desa adat telah di revitalisasi maka secara tidak langsung desa adat akan terrevitalisasi dengan sendirinya.

1. Wujud Revitalisasi Desa Adat Berbasis Pendidikan Pada Masyarakat Kabupaten Lampung Barat

Pendidikan sebagai kebutuhan manusia yang mendasar sangat perlu mendapat perhatian lebih dan peningkatan kualitas pendidikan terdapat pada guru sebagai garda terdepan dalam proses pembelajaran dan pendidikan. Kualitas guru sebagai tenaga pendidik akan sangat berpengaruh pada peningkatan kualitas sumber daya manusia dan secara langsung juga akan meningkatkan mutu pendidikan di daerah tersebut.

Selain dikarenakan faktor kurikulum yang berubah secara cepat dan tanpa adanya sosialisasi. Masalah tersebut seolah diperparah dengan kompetensi guru di desa adat Kabupaten 
Lampung Barat yang masih dibawah standar yang diharapkan. Hal itu terjadi karena perilaku malas yang sudah menjadi kebiasaan bagi sebagian tenaga pendidik ditambah lagi dengan rasa keinginan untuk berbuat lebih.yang masih sangat minim. Disamping itu juga kreatifitas serta inovasi yang dilakukan masih sangat kurang sehingga hal tersebut cenderung membuat perilaku konsumtif di kalangan tenaga pendidik.

Solusi atas permasalahan pendidikan di desa adat Lampung Barat sebagai upaya peningkatan kualitas pendidikan dan mutu sumber daya manusia yang berdaya saing dapat ditempuh dengan berbagai langkah konkrit dan rencana strategis diantaranya peningkatan kesiapan guru dalam menghadapi perubahan kurikulum yang dinamis serta tantangan tuntutan zaman yang terus berkembang dan pengembangan kompetensi guru berbasis pada budaya dan kearifan lokal.

a. Peningkatan kesiapan guru dalam menghadapi perubahan kurikulum yang dinamis serta tantangan dan tuntutan zaman yang terus berkembang

Kebijakan yang terbaru dari pemerintah berkaitan dengan kurikulum yaitu dikeluarkannya dan disahkannya perubahan kurikulum dari yang sebelumnya Kurikulum Tingkat Satuan Pendidikan (KTSP) menjadi Kurikulum 2013 (K13) meskipun kurikulum 2013 belum dapat diterapkan di seluruh provinsi yang ada di Indonesia namun kini kurikulum 2013 sudah mulai diterapkan diberbagai provinsi dan jenjang pendidikan salah satunya yaitu di Kabupaten Lampung Barat. Kesiapan guru dalam menghadapi perubahan kurikulum harus disiasati dengan cara meningkatkan kesiapan guru dalam mengimplementasikan kurikulum. Kesiapan guru dalam mengimplementasikan kurikulum tidak hanya dilihat dari seberapa besar tingkat pemahaman guru tentang kurikulum, tetapi dilihat juga dari seberapa besar tingkat kemampuan guru dalam mengimplementasikan kurikulum dalam pembelajaran yang meliputi: merencanakan, melaksanakan, dan menilai pembelajaran. Hal itu menunjukkan bahwa kesiapan guru dalam mengimplementasikan kurikulum sudah mengandung dua aspek kemampuan baik teoritis maupun aplikatif. Dengan kesiapan guru yang demikian dapat mengindikasikan berhasil tidaknya guru dalam mengimplementasikan kurikulum dalam pembelajaran. 
Berikut ini adalah tabel ringkasan hasil analisis tentang kesiapan guru di Kabupaten Lampung Barat dalam mengimplementasikan kurikulum 2013 baik secara akumulatif maupun dilihat perdimensi, yaitu: pemahaman guru tentang kurikulum 2013, kemampuan guru dalam merencanakan, melaksanakan, dan menilai pembelajaran. Untuk lebih jelasnya dapat dilihat pada berikut.

Tabel 1. Dimensi Kesiapan Guru dalam Mengimplementasikan Kurikulum 2013

\begin{tabular}{|c|c|c|c|}
\hline No. & $\begin{array}{c}\text { Dimensi Kesiapan Guru dalam } \\
\text { Mengimplementasikan Kurikulum } \\
2013\end{array}$ & $\begin{array}{l}\text { Capaian } \\
(\%)\end{array}$ & Kategori \\
\hline 1. & $\begin{array}{l}\text { Pemahaman guru tentang } \\
\text { Kurikulum } 2013\end{array}$ & 71.10 & Baik \\
\hline 2. & $\begin{array}{l}\text { Kemampuan guru dalam } \\
\text { merencanakan pembelajaran }\end{array}$ & 63.77 & Cukup \\
\hline 3. & $\begin{array}{l}\text { Kemampuan guru dalam } \\
\text { melaksanakan pembelajaran }\end{array}$ & 51.17 & Rendah \\
\hline 4. & $\begin{array}{l}\text { Kemampuan guru dalam menilai } \\
\text { pembelajaran }\end{array}$ & 64.43 & Cukup \\
\hline 5. & $\begin{array}{l}\text { Kesiapan guru dalam } \\
\text { mengimplementasikan Kurikulum } \\
2013\end{array}$ & 62.61 & Cukup \\
\hline
\end{tabular}

Sumber: Pengolahan Data Dimensi Kesiapan Guru di Lampung Barat

Berdasarkan tabel diatas terlihat bahwa dimensi kemampuan guru dalam merencanakan, dan menilai pembelajaran mempunyai skor rerata yang hampir sama, yaitu sebesar 63,77\%, dan 64,43\%. Keduanya termasuk dalam kategori cukup. Sedangkan, dimensi kemampuan guru dalam melaksanakan pembelajaran mempunyai skor terendah, yaitu sebesar $51.17 \%$ dan termasuk kategori rendah. Jika keempatnya dirata-rata akan mencerminkan skor rerata kesiapan guru di Kabupaten Lampung Barat dalam mengimplementasikan kurikulum 2013 yaitu sebesar 62,61\% dan termasuk dalam kategori cukup.

Dari hasil analisis di atas, secara umum memberi gambaran bahwa kesiapan guru Kabupaten Lampung Barat dalam mengimplementasikan kurikulum 2013 termasuk dalam kategori 
rendah. Hal tersebut dapat dilihat dari rerata skornya yang berada di batas bawah kategori baik (70\%). Hasil yang demikian tentu masih jauh dari target dan masih sangat perlu dilakukan peningkatan diberbagai dimensi, terlebih ada satu dimensi kesiapan guru yang masih termasuk kategori rendah, yaitu kemampuan guru dalam melaksanakan pembelajaran.

Ternyata masih cukup banyak kelemahan-kelemahan tentang kesiapan guru dalam mengimplementasikan kurikulum 2013. Apabila dirangkum kelemahan-kelemahan di atas terutama terkait dengan hal-hal yang baru dari kurikulum 2013 yang berbeda dari kurikulum sebelumnya, seperti pemahaman tentang pembelajaran saintifik, penggunaan media yang bervariasi, mengaktifkan pesesrta didik, melaksanakan penilaian autentik, melaksanakan remidi atau pengayaan. Hal tersebut dapat dimaklumi karena memang terjadi perubahan yang sangat mendasar menurut kurikulum 2013. Dengan perubahan yang mendasar tersebut guru memerlukan waktu untuk menyesuaikan dengan perubahan-perubahan tersebut.

Untuk meningkatkan kesiapan guru dalam mengimplementasikan kurikulum 2013 perlu dilakukan berbagai upaya yang sinergi dan komprehensif yang harus dilakukan para pemangku kepentingan baik oleh guru, kepala sekolah, pengawas, maupun oleh pejabat pemerintah daerah maupun pusat yang terkait. Tanpa ada usaha keras dari berbagai pihak sangat sulit mewujudkan implementasi kurikulum seperti yang diharapkan.

Untuk itu masing-masing pihak harus melakukan upayaupaya sebagai berikut: 1) Para guru hendaknya tidak berhenti usahanya sampai pada mengikuti pelatihan saja, akan tetapi selalu meningkatkan pemahaman dan kemampuannya dalam mengelola pembelajaran yang sesuai dengan kurikulum 2013 baik melalui belajar mandiri, diskusi dengan teman sejawat, aktif dalam kegiatan MGMP, seminar dan forum-forum ilmiah lainya, dan meningkatkan kemampuan serta keinginan guru dalam melaksanakan pembelajaran; 2) Kepala sekolah hendaknya selalu mendorong, memfasilitasi, mendampingi, membantu, membimbing, membina, dan memberdayakan para guru melalui pembimbingan, workshop dan pelatihan-pelatihan yang terprogram dan berkelanjutan; 3) Pengawas sekolah hendaknya mengoptimalkan tugas dan fungsinya untuk mendampingi, 
membantu, membimbing, dan mengawasi guru dengan lebih aktif; 4) Pejabat pendidikan tingkat daerah dan pusat hendaknya melakukan pembinaan, memberikan dan melengkapi perangkat dan fasilitas yang diperlukan menyelenggarakan, pelatihan dan workshop yang berkesinambungan, dan menghidupkan klinik pembelajaran baik secara offline maupun online. Dengan upaya berbagai pihak yang bersinergi maka diharapkan kesiapan guru di desa adat Kabupaten Lampung Barat dalam mengimplementasikan kurikulum 2013 akan lebih baik.

b. Pengembangan kompetensi guru berbasis pada budaya dan kearifan lokal

Sebagai negara yang memiliki jumlah budaya dan kearifan lokal yang cukup banyak maka dipandang perlu untuk dilakukan pengembangan kompetensi guru yang mampu mengakomodir seluruh tujuan pembelajaran melalui budaya dan kearifan lokal sebagai sarana pengajaran. Istilah kompetensi secara umum dimaknai sebagai kemampuan, keterampilan dan pengetahuan yang dimilki seseorang untuk dapat melakukan sesuatu dengan baik sesuai standar yang ditentukan. ${ }^{10}$

Kompetensi budaya sebagai salah satu aspek kompetensi guru diperlukan untuk meningkatkan efektivitas dan kebermaknaan program pendidikan pada berbagai jenis dan jenjangnya. Kompetensi budaya merupakan proses perkembangan meningkat dan meluas sejalan dengan eksistensi individu pada tingkat kesadaran, pengetahuan, dan keterampilan yang bersifat kontinu.

Pengembangan kompetensi budaya menuntut guru dengan seperangkat pengetahuan, sikap dan keterampilan untuk berinteraksi dengan berbagai latar belakang budaya peserta didik. Dengan pemahaman yang baik terhadap kergaman budaya peserta didiknya guru dapat berperan dalam kontekstual dan peningkatan kebermaknaan pembelajaran dalam proses pendidikan yang berlangsung di sekolah.

Realitas persoalan diatas perlu diformulasikan sehingga dapat melahirkan suatu pendidikan kontekstual guna menjawab persoalan tesebut, yakni pendidikan tanpa harus mengabaikan

10 Oxford University, Oxford Learner's Pocket Dictionary. Fourth Edition (New York: Oxford University Press, 2011). 
lokalitas sebagai satu nilai lebih. Apabila strategi ini diimplementasikan, dampaknya anak atau peserta didik tidak lagi kehilangan nilai dasar kulturalnya, anak tidak kehilangan akar sejarahnya serta memiliki wawasan pengetahuan atas penyikapan realitas sosial dan lingkungannya.

Pengembangan kompetensi guru berbasis pada budaya dan kearifan lokal berpijak pada asumsi bahwa untuk melahirkan guru yang mempunyai kompetensi budaya salah satu syarat utamanya adalah mengenalkan budaya dan kearifan lokal sejak dini melalui kurikulum pendidikan guru. Harapan untuk mendapatkan guru yang mempunyai kompetensi budaya tidak akan terwujud apabila tidak disertai dengan kesadaran, kemauan, dan tekad untuk mengintegrasikan budaya atau kearifan lokal dalam pendidikan guru. Menurut Vavrus pendidikan guru menempatkan posisi sangat menentukan dalam pengembangan guru yang mempunyai perspektif budaya dan multicultural dalam menjalankan tugas pengajaran di sekolah. ${ }^{11}$

Pengembangan pendidikan guru memiliki peran strategis dalam merekonstruksi keyakinan guru dalam memperkenalkan dan menjadikan nilai kergaman budaya dalam keseluruhan aktivitas yang diselenggarakan. Dalam Castagno dan Brayboy menyatakan bahwa guru berkompetensi budaya mempunyai karakteristik dapat menghubungkan model pemerolehan pengetahuan yang berkembang dalam masyarakat lokal dengan pelaksanaan tugasnya sebagai guru. ${ }^{12}{ }^{12}$ Sejumlah teori pendidikan juga menempatkan budaya sebagai bagian esensial pendidikan dan memberi kontribusi penting terhadap kompetensi guru berbasis budaya dan kearifan lokal. Diterimanya budaya dan kearifan lokal dalam pendidikan memberikan sudut pandang pentingnya lensa budaya dalam meningkatkan kesetaraan, kualitas, dan kebermaknaan pendidikan.

Sue merumuskan kompetensi budaya pada tataran individu yang dapat ditempuh oleh guru dengan memperhatikan empat prinsip berikut: Pertama, memperluas perspektif mengenai budaya.

11 Vavrus, M, Transforming the Multicultural Education of Teachers. (New York: Teachers College, 2002).

${ }^{12}$ Castagno, A.E., Brayboy, B.M.J, "Culturally Responsive Schooling for Indigenous Youth: A Review of Literature" dalam Review of Educational Research, Vol 78 (4), 2008, h. 941-993. 
Kedua, untuk memperoleh gambaran utuh mengenai profil budaya diperlukan waktu yang lama. Ketiga, adanya upaya melengkapi pemahaman faktual dan aktual. Keempat, perlu sikap kehati-hatian sehingga tidak memunculkan sikap bias. ${ }^{13} 13$

Pengetahuan dan kearifan lokal ini merupakan realitas yang pasti ada dan dimiliki oleh setiap masyarakat. Sifatnya sangat spesifik, serta terbentuk melalui pengalaman dan perjalanan kehidupan masyarakat yang bersangkutan. Bagi Soetomo setiap masyarakat mempunyai pengalaman kehidupan yang berbeda, maka pengetahuan dan kearifan lokal bentuk dan sifatnya juga bervariasi antarmasyarakat yang berbeda. ${ }^{14}$

Kompetensi budaya guru mengisyaratkan kemampuan guru yang tercakup dalam ranah pengetahuan, sikap, dan keterampilan yang berakar pada budaya peserta didik. Guru yang mempunyai kompetensi budaya tidak hanya menguasai materi dan metode pembelajaran, tetapi juga mampu memperkaya materi dan metode pembelajaran dengan khazanah kearifan lokal, sehingga peserta didik lebih mudah menangkap substansi materi pembelajaran, menumbuhkan sikap lebih positif terhadap warisan budaya, dan dapat meningkatkan kebermaknaan proses pendidikan.

2. Wujud Revitalisasi Desa Adat Berbasis Kearifan Lokal Pada Masyarakat Kabupaten Lampung Barat

Keberagaman budaya dan suku bangsa dalam ruang lingkup masyarakat yang majemuk di Indonesia telah melahirkan kekayaan kearifan lokal. Kearifan lokal merupakan salah satu sumber pengetahuan (kebudayaan) masyarakat, ada dalam tradisi dan sejarah, dalam pendidikan formal dan informal, seni, agama dan interpretasi kreatif lainnya. Revitalisasi desa adat berbasis kearifan lokal menjadi sangat penting bahkan harus mendapat prioritas untuk menjaga kebhinekaan dan potensi kearifan lokal agar tidak tergerus oleh gaya hidup modern. Alasan pentingnya revitalisasi desa adat berbasis kearifan lokal diantaranya selain agar terjaganya identitas budaya masyarakat Kabupaten Lampung Barat tetapi juga sebagai

13 Sue, D, W, "Multidimensional Facets of Cultural Competence" dalam The Counseling Psychologist, Vol 29 (6), 2001, h. 790-821.

14 Soetomo, Keswadayaan Masyarakat, Manifestasi Kapasitas Masyarakat untuk Berkembang secara Mandiri (Yogyakarta: Pustaka Pelajar, 2012) h. 116 
upaya untuk menjadikan kearifan lokal sebagai sarana penanaman nilai-nilai dan pedoman yang terkandung didalamnya.

Kearifan lokal di dalamnya berisi nilai hidup yang lahir dari dalam masyarakat itu sendiri dan digunakan untuk megatur kehidupan sosial. Di tengah-tengah arus globalisasi dan modernisasi yang semakin pesat dan terlebih banyaknya berbagai kegiatan berskala internasional maka dikhawatirkan akan menimbulkan efek negatif berbagai permasalahan dan melemahnya budaya bangsa. Dan secara tidak langsung keberlangsungan kearifan lokal sebagai salah satu identitas budaya bangsa akan terancam. Di samping itu juga secara berangsur-angsur akan ada perubahan sosio-kultural pada kehidupan masyarakat.

Melihat hal tersebut maka dalam menjaga keberlangsungan desa adat pemerintah perlu mengupayakan revitalisasi desa adat berbasis kearifan lokal sebagai salah satu basis pembentukan identitas dan karakter bangsa dan sebagai salah satu langkah solusi atas persoalan sosial di Kabupaten Lampung Barat. Pemerintah dan masyarakat perlu menggunakan konsepsi piil pesenggiri sebagai pedoman masyarakat Lampung untuk menjawab persoalan tersebut. Melalui konsepsi piil pesenggiri tersebut lokalitas atau kearifan lokal sebagai satu unsur pembentuk jati diri bangsa dan sebagai salah satu solusi atas persoalan sosial di Kabupaten Lampung Barat agar dapat semakin baik.

Konsepsi piil pesenggiri sebagai pandangan hidup dituangkan kedalam empat pilar filosofi dan mengandung nilai-nilai tatanan dalam kehidupan bermasyarakat. Menurut Farida A. dkk, nilai yang terkandung dalam keempat filosofi tersebut adalah 1. Bejuluk Buadok (menjaga kepribadian sesuai dengan gelar yang disandang) 2. Nengah Nyappur (aktif dalam pergaulan bermasyarakat dan tidak individualistis) 3. Nemui Nyimah (saling mengunjungi dan menjaga silaturahmi) 4. Sakai Sambaian (gotong royong dan saling membantu). ${ }^{15}$

Kabupaten Lampung Barat sebagai salah satu kabupaten yang seharusnya masih menjaga dan melestarikan kekhasan kearifan lokal yang terkandung dalam konsepsi piil pesenggiri sebagai pedoman bermasyarakat kini lambat laun sudah mulai

15 Ariyani, Farida, Konsepsi Piil Pesenggiri Menurut Masyarakat Adat Lampung Waykanan Di Kabupaten Waykanan. (Lampung: Aura Publishing, 2014) h. 79. 
meninggalkan konsepsi tersebut dan cenderung mengadopsi kehidupan budaya barat. Padahal dalam konsepsi piil pesenggiri tersebut sudah terkandung dengan jelas pedoman tatanan kehidupan bermasyarakat dan masih sangat relevan untuk dijalankan.

Menurut Efendi Sanusi falsafah hidup adalah anggapan, gagasan, dan sikap batin yang paling dasar yang dimiliki oleh seseorang atau sekelompok masyarakat. ${ }^{16}$ Pandangan/ falsafah hidup berfungsi sebagai pengikat di dalam suatu kehidupan sosial. Adapun penelitian ini memahami bahwa pandangan hidup cukup memberikan pengaruh atas terbentuknya tingkah laku manusia di dalam hidupnya sehari-hari. Nilai dasar kultural yang tercermin dalam pandangan hidup menjadi satu hal yang penting. Masyarakat dapat bersosialisasi atau membaur tanpa harus tercerabut dari induk budayanya. Apabila masyarakat mampu memahami dan mengimplementasikan pandangan hidup berbasis kearifan lokal dalam bermasyarakat, maka sangat mungkin dirinya tak lagi terasing oleh lingkungan budayanya.

Kearifan lokal termanifestasi dalam berbagai bentuk, misalnya dalam tradisi, nilai-nilai moralitas dan panduan hidup. Kearifan lokal juga tertuang dalam petuah-petuah kehidupan yang ditransmisi melalui tradisi lisan dan hanya sebagian kecil ditransmisikan secara tertulis. Secara lebih spesifik, kearifan lokal dapat dikelompok-kan menjadi lima: kearifan yang berupa pandangan hidup, kepercayaan atau ideology yang diungkapkan dalam kata-kata bijak (filosofi); kearifan yang berupa sikap hidup sosial, nasihat atau iktibar yang diungkap dalam bentuk pepatah, perumpamaan, pantun syair atau cerita rakyat (folklor); kearifan berupa ritus atau seremoni dalam bentuk upacara; kearifan yang berupa prinsip, norma, dan tata aturan bermasyarakat yang berwujud menjadi sistem sosial; dan kearifan yang berupa kebiasaan, prilaku sehari-hari dalam pergaulan sosial. ${ }^{17}$ 2014) h. 4..

16 Sanusi, Efendi, Sastra Lisan Lampung (Lampung: Universitas Lampung,

17 Rasyidin, Siregar, P. Batubara, K, Penyerapan Nilai-Nilai Budaya Lokal dalam Kehidupan Beragama: Studi Tentang Budaya Lokal di Medan dalam Afif dan Bahri, S.Ed, Harmonisasi Agama dan Budaya di Indonesia. (Jakarta: Balitbang Kemenag, 2009), h 236. 
Tersampaikannya pandangan hidup yang bersumber dari kearifan lokal, membuat masyarakat memiliki tolak ukur terhadap pandangan ala Barat. Di sinilah letak pentingnya kearifan lokal dibangun sejak di lingkungan desa adat. Mengingat pada tahap ini nilai-nilai dasar kultural yang ada di dalam kearifan lokal melekat pada diri masyarakat. Memegang teguh nilai-nilai kearifan lokal dan mengimplementasikannya pada kehidupan bermasyarakat akan mampu menjadi solusi atas timbulnya permasalahan sosio-kultural dan lunturnya pandangan hidup piil pesenggiri pada masyarakat Kabupaten Lampung Barat.

\section{Penutup}

Dalam konteks budaya dan masyarakat hadirnya desa adat sebagai wadah pemersatu antara keragaman budaya dan kehidupan bermasyarakat akan sangat relevan dijalankan sebagai satu kesatuan utuh yang terintegrasi dengan adat istiadat yang ada. Desa adat mampu dijadikan solusi sebagai media penghubung antara kehidupan sosial budaya yang majemuk dengan dibatasi aturan-aturan adat istiadat yang berlaku dan menjadi pedoman dalam bermasyarakat.

Hadirnya desa adat sebagai salah satu penopang suatu daerah memiliki posisi yang sangat strategis dalam kemajuan daerah tersebut. Revitalisasi berbagai aspek pendukung desa adat akan berdampak pada peningkatan kualitas desa adat dan secara tidak langsung turut memberikan andil positif terhadap kemajuan daerah tersebut. Kemajuan desa adat sangat bergantung dari berbagai komponen pendukung yang cukup penting salah satunya yaitu aspek pendidikan dan aspek kearifan lokal.

Dalam tataran desa adat pada masyarakat Kabupaten Lampung Barat pendidikan telah menjadi salah satu unsur adat yang harus terpenuhi. Mulai dari sistem pendidikan yang ada sampai dengan ujung tombak terdepan pendidikan yaitu guru atau tenaga pendidik. Sebagaimana kita ketahui kualitas masa depan bangsa ditentukan dari kualitas tenaga pendidik hari ini.

Untuk meningkatkan kesiapan guru dalam menghadapi berbagai tantangan dan tuntutan zaman kedepan perlu dilakukan berbagai upaya yang sinergi dan komprehensif yang harus dilakukan para pemangku kepentingan baik oleh guru, kepala 
sekolah, pengawas, maupun oleh pejabat pemerintah daerah maupun pusat yang terkait. Guru yang mempunyai kompetensi budaya tidak hanya menguasai materi dan metode pembelajaran, tetapi juga mampu memperkaya materi dan metode pembelajaran dengan khazanah kearifan lokal, sehingga peserta didik lebih mudah menangkap substansi materi pembelajaran, menumbuhkan sikap lebih positif terhadap warisan budaya, dan dapat meningkatkan kebermaknaan proses pendidikan.

Revitalisasi desa adat berbasis kearifan lokal menjadi sangat penting bahkan harus mendapat prioritas untuk menjaga kebhinekaan dan potensi kearifan lokal agar tidak tergerus perkembangan zaman dan oleh gaya hidup modern. Memegang teguh nilai-nilai kearifan lokal dan mengimplementasikannya pada kehidupan bermasyarakat akan mampu menjadi solusi atas timbulnya permasalahan sosio-kultural dan lunturnya pandangan hidup piil pesenggiri pada masyarakat Kabupaten Lampung Barat. []

\section{DAFTAR PUSTAKA}

Ariyani, Farida, Konsepsi Piil Pesenggiri Menurut Masyarakat Adat Lampung Waykanan Di Kabupaten Waykanan, Lampung: Aura Publishing, 2014.

Bachtiar, Harsya, W, "Konsesnsus dan Konflik dalam Sistem Budaya di Indonesia", dalam Harsya. W. Bachtiar, Mattulada, Haryati Soebadio. Budaya dan Manusia Indonesia. Yogyakarta: Hanindita, 1985.

Castagno, A.E., Brayboy, B.M.J, "Culturally Responsive Schooling for Indigenous Youth: A Review of Literature" dalam Review of Educational Research, 78 (4), 941-993, 2008.

Gay, G, Culturally Responsive Teaching: Theory, Research and Practice, New York: Teacher College, 2000.

Oxford University. Oxford Learner's Pocket Dictionary. Fourth Edition. New York: Oxford University Press, 2014.

Rasyidin., Siregar, P., Batubara, K, "Penyerapan Nilai-Nilai Budaya Lokal dalam Kehidupan Beragama: Studi Tentang Budaya Lokal di Medan" dalam Afif dan Bahri, S. Ed. Harmonisasi Agama dan Budaya di Indonesia. Jakarta: Balitbang Kemenag, 2009. 
Sanusi, Efendi, Sastra Lisan Lampung, Lampung: Universitas Lampung, 2014.

Soetomo, Keswadayaan Masyarakat, Manifestasi Kapasitas Masyarakat untuk Berkembang secara Mandiri, Yogyakarta: Pustaka Pelajar, 2014.

Strauss, Anselm, dan Corbin, Juliet, Dasar-dasar Penelitian Kualitatif, Tatalangkah dan Teknik-teknik Teoritisasi Data, Yogyakarta: Pustaka Pelajar, 2009.

Sue, D, W, "Multidimensional Facets of Cultural Competence" dalam The Counseling Psychologist, 29 (6), 790-821, 2001.

Tilaar, H.A.R, Pedagogik Teoritis untuk Indonesia, Jakarta: Buku Kompas, 2015.

Undang-Undang Republik Indonesia Nomor 6 Tahun 2014 Tentang Desa.

Vavrus. M, Transforming the Multicultural Education of Teachers. New York: Teachers College, 2002.

\section{Jurnal:}

Mufid, Syafi'i, A, Revitaliasi Kebudayaan Lokal dalam Pemberdayaan Masyarakat, dalam Jurnal Multikultural dan Multireligius, Vol. IX, Nomor 34.

Musanna, Al, Artikulasi Pendidikan Guru Berbasis Kearifan Lokal Untuk Mempersiapkan Guru yang Memilki Kompetensi Budaya, dalam Jurnal Pendidikan dan Kebudayaan, Vol. 18, Nomor 3, Aceh Tengah: STAIN Gajah Putih Takengon, 2012.

Villegas, A.M. Lucas, T, "Preparing Culturally Responsive Teachers: Rethinking Curriculum" dalam Journal of Teacher Education, 53 (1), 20-32, 2002. 